\title{
Independence principle and its exception in letter of credit law: Suggestions for Vietnam
}

\author{
Bui Le Thuc Linh ${ }^{1,2}$,*
}

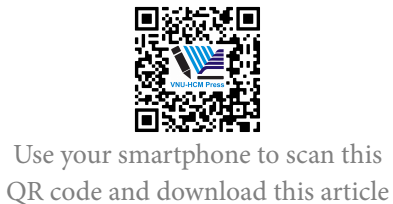

${ }^{1} P h D$ student at Géza Marton Doctoral School of Legal Studies- University of Debrecen

${ }^{2}$ Lecturer at University of Economic and Law, VNUHCM, Vietnam

Correspondence

Bui Le Thuc Linh, PhD student at Géza Marton Doctoral School of Legal Studies- University of Debrecen

Lecturer at University of Economic and Law, VNUHCM, Vietnam

Email: linhblt@uel.edu.vn

History

- Received: 07/04/2020

- Accepted: 21/9/2020

- Published: 07/10/2020

DOI : 10.32508/stdjelm.v4i4.591

\section{Check for updates}

\section{Copyright}

(.) VNU-HCM Press. This is an openaccess article distributed under the terms of the Creative Commons Attribution 4.0 International license.

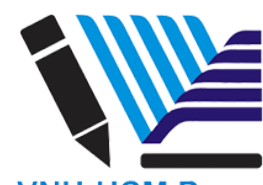

VNU-HCM Press

\begin{abstract}
Even though the letter of credit was invented from a long time ago, however, its legal personalities are very new to the Vietnam Legal Framework. The International Chamber of Commerce ("ICC") has issued principles for the documentary credit which is the Uniform of Customs and Practice ("UCP") since 1933 and kept updating it until now, the latest version of UCP is UCP 600 which is presented in 2007. However, the UCP has not systematized many aspects of documentary credit yet and ICC considered those problems as subjects of domestic regulations. The diversification in different national laws leads to confusion thus causing many problems to merchants in international trade. Some countries do not have specified codifications to regulate the letter of credit so these countries treat UCP as "quasi-law" while other countries have their own legal framework for letter of credit law and even have fraud rules included. It is quite interesting that the United States which is a common law country is the first country to embody the operation of letter of credit in the Uniform of Commercial Code ("UCC") and regulates the fraud rule within the same Code. This paper will try to explain and compare the principle of independence in the UCP and UCC, clarify the definition and regulations of fraud rule in UCC and evaluate the legal regulations of Vietnam law for the independence principle in a letter of credit.

Key words: Letter of credit, fraud, fraud rule, UCP, UCC
\end{abstract}

\section{INTRODUCTION}

International business always have higher risks than domestic business. Most of the merchants doing trade in the international market does not have specified information about their trading partners and as a results, it is very risky for seller to ship the goods before receiving money or the buyer might face the possibility of losing money if he pays before the goods land the arriving port, the seller will not send the products. Due to the unreliability between parties, documentary credit was fashioned by mercantile usage. The documentary credit removes the risk for not being paid of the seller as well as make sure the buyer does not have to pay money until a set of documents whose title demonstrating the ownership of the cargos presented to the bank- third party.

The letter of credit has two basic principles and the independence principle is one of the rules. Within this principle, the obligation of a bank is separated and does not depend on a transaction which is used for issuing that letter of credit. Nowadays, the letter of credit are very common and is mostly governed by Uniform Customs and Practices. However, the Uniform Customs and Practice still leaves some problems for the domestic law, one of those is fraud rule. The remittance of the documentary credit is unstoppable, nonetheless, this process is vulnerable if the frauds are involved. According to the fraud rule in UCC, once fraud is found, even the document tendered strictly seemingly comply to the obligations required in the documentary credit, the remittance for the beneficiary may be halted if frauds are involved within the drafts or in the sales contract. Fraud rule is regulated in some national principles such as United States or China. A regulation for letter of credit and fraud exception would prevent overwhelming litigations. This not only enhances the obligations of parties but also remains the commerce utility of letter of credit, makes letter of credit is still recognized as a favorable finance device of international trade.

\section{INTERNATIONAL LETTER OF CREDIT LAW AND ITS NATURE}

\section{Uniform Customs and Practices}

The letter of credit is a product resulted from the international trading customs. International Chamber of Commerce ("ICC") tried to summarize these customs in an effort to create a written international rules for letter of credit, which is known as Uniform of Customs and Practices ("UCP”). UCP was first perfected 
in $1933^{\mathrm{a}}$ through a great effort of ICC to uniform the rules governing the letter of credit $\left[{ }^{1}\right.$, pp. 578 579]. This first version was adopted in some European countries and some financial institutions in the United States. However, United Kingdom and Commonwealth countries turned this version down. Afterward, ICC came up with the new version of UCP in $1951^{\mathrm{b}}$ and at that time UCP 1951 was embraced by several countries in the world, however, United Kingdom and Commonwealth countries still refused to obtain these rules $\left[{ }^{1}\right.$, p. 579$]$.

Thereafter, ICC tried to revise the UCP again in 1962 and notonlyuntil $1983^{\mathrm{C}}$ that the UCPwaswidely accepted and itkept up with the changes of the law in the fields $\left[{ }^{2}\right.$, p. 110]. This version focused on different issues such as the negotiation of the document of documentary credit, the adoption of the new type of letter of credit and the new technologies used in the transmission like SWIFT- Society for Worldwide Interbank Financial Telecommunications $\left[{ }^{1}\right.$, p. 582]. In this version, UCP started to apply for both standby letter of credit and commercial letter of credit. Afterward, the UCP was revised again in $1993^{\mathrm{d}}$ to improve the function of the UCP because nearly fifty percent of the documents tendered were turn down by banks ${ }^{3}$. This version is recognized as ICC Publication No. 500 or UCP 500. The latest version is UCP 600 and is valid on 01 July 2007. UCP 600 has 39 articles and applies to "bankers, lawyers, importers, and exporters, transport executives, educators, and everyone involved in letter of credit transactions worldwide" ${ }^{4}$.

The reasons for the successful of UCP are because it harmonizes financial measures in international trading customs and dismissing the technical barrier which affect to the smooth operation of letter of credit. These days, UCP governs most of letter of credit $\left[{ }^{2}\right.$, p. 112]. Even though the UCP defines liability and responsibility of parties in the letter of credit and is widely accepted in many countries in the world, it is still not considered as law. According to Professor Ellinger, UCP should be considered as "de facto law" $\left[{ }^{1}\right.$, p. 578]. The rules of UCP are universally used in many courts because of the existing industrial practices reflected in it $\left[{ }^{2}\right.$, p. 113$]$.

\footnotetext{
${ }^{\mathrm{a}}$ International Chamber of Commercial, ICC brochure No. 82 , 1933.

${ }^{\mathrm{b}}$ International Chamber of Commerce, ICC Brochure No. 151, 1951.

${ }^{\mathrm{c}}$ International Chamber of Commerce, ICC Brochure No. 400, 1984.

${ }^{\mathrm{d}}$ International Chamber of Commerce, ICC Publication No. 590, 1998
}

\section{The nature of Letter of Credit}

Letter of credit are defined under the Article 2 of The Uniform Customs And Practice For Documentary Credit ("UCP") which is a set of regulations that govern the operation of letter of $\mathrm{credit}^{4}$, as follows:

- "Credit means any arrangement, however named or described, that is irrevocable and thereby constitutes a definite undertaking of the issuing bank to honor a complying presentation.".

Within the definition, the letter of credit is interpreted as an irrevocable mechanism, in which the issuer commits to honor a request to grant money or a draft presented by beneficiary meeting the requirements specified under the letter of credit. Since international businessmen have been used the letter of credit for a long time, its functions are varied which led to different kinds of letter of credit. Heretofore, there has been no confirmation yet about the time when the letter of credit adopted its current form. Professor Ellinger concluded that modern letter of credit took its form around 1840 and became "respectable" about 1849 [ ${ }^{5}$, p. 29], which is in the middle of the $19^{\text {th }}$ century and thoroughly perfected after the First World War $\left[{ }^{5}, \mathrm{p}\right.$. 37]. The modern letter of credit can be carved out two forms: standby letter of credit and commercial letter of credit [ ${ }^{6}$, pp. 735-739]. Commercial letters of credit are considered as the classic form of letter of credit $\left[{ }^{2}\right.$, p. 95] and are used as an instrument to pay for the seller in the international sales contracts which the letter of credit is based on [ ${ }^{7}$, p. 359]. Standby letters of credit conduct the legal framework which is similar to commercial letter of credit. tandby letters of credit are normally adopted by considerable range of transactions and it is usually used in the construction industry, financial industry or in sale of goods to guarantee the performance of the good purchased [ ${ }^{2}$, p. 99].

In an ordinary letter of credit, there are three main participants ${ }^{8}$

1. The applicant, known as "the buyer" or "the customer"

2. The beneficiary, or "the seller"

3. The bank, known as "the issuing bank" or "issuer".

Among three parties, the three transactions in the commercial letter of credit are: 
1. The underlying contract between the seller and the buyer, in which specifies the rights and obligations of parties. Under the terms and conditions in the agreement, the seller commits the obligation to sell their goods and the buyer promises to reimburse the seller $\left[{ }^{9}\right.$, p. 40$]$. This contract also provide that the buyer has to carry out payment for the seller by the documentary credit $\left[{ }^{7}\right.$, p. 361$]$;

2. The agreement between the issuing bank and the buyer, in which the issuer conforms to issue a letter of credit in favor of the seller, then the buyer agrees to pay back the issuing bank for the amount that they pay for seller in the letter of credit $\left[{ }^{9}\right.$, p. 40$]$, this transaction is also called reimburse contract $\left[{ }^{7}\right.$, p. 361$]$;

3. The letter of credit itself, or the transaction between the seller (now called "beneficiary") and the issuing bank. This is an irrevocable promise of the bank to honor the documents as long as the documents meets the requirements specified in the letter of credit $\left[{ }^{7}\right.$, p. 363$]$.

Like commercial letter of credit, standby letter of credit also contain three participants (the applicant, the beneficiary and the issuer) and three transactions (the sales contract, the application to open the letter of credit and the letter of credit itself) [ ${ }^{2}$, p. 99].

The transactions in the letter of credit "have a high degree of commercial utility" $\left[{ }^{2}\right.$, p. 100]. Under these agreements, the seller remains his possession for his goods until he tenders the drafts to the bank to get reimbursement or waits until the issuer to accept his drafts. The seller would not worried about non-payment because the issuer commit to pay for the draft as long as the drafts include required documents. The buyer also faces no risks to lose his money cause his payment will not be released until the beneficiary presents the requirement drafts $\left[{ }^{2}\right.$, p. 100].

\section{INDEPENDENCE PRINCIPLE IN INTERNATION REGULATIONS AND NATIONAL LAW}

\section{Independence principle in Uniform Cus- toms and Practices}

The center of the documentary credit law is the independence principle. According to this principle, the obligation of the issuing bank is to pay for the documents tendered by beneficiary, this commitment is separated and ultimately independence from the sales contract between the seller and the buyer and the reimburse contract between the bank issuer and the applicant. The issuing bank must honor the drafts and its obligation to the beneficiary even though there are any problems or conflict within the sales contract between seller and buyer $\left[{ }^{10}\right.$, p. 957].

The independence principle is emphasized in Article 5 of UCP 600 as follows: "Banks deal with documents and not with goods, services or performance to which the documents may relate". In consonance with this provision, the bank issuers focus mostly on the documents, goods and service are not included within the scope of issuing banks' involvement. This principle is also brighten more in Article 34 as follows:

- "A bank assumes no liability or responsibility for the form, sufficiency, accuracy, genuineness, falsification or legal effect of any document, or for the general or particular conditions stipulated in a document or superimposed thereon; nor does it assume any liability or responsibility for the description, quantity, weight, quality, condition, packing, delivery, value or existence of the goods, services or other performance represented by any document, or for the good faith or acts or omissions, solvency, performance or standing of the consignor, the carrier, the forwarder, the consignee or the insurer of the goods or any other person."

Article 4 also point out that the banks are separate to the other contract of the letter of credit "Banks are in no way concerned with or bound by such contract, even if any reference whatsoever to it is included in the credit." Accordingly, the only concern of issuer in the documentary credit negotiation is evaluating whether the documents declared by the beneficiary meet the requirements specified in the letter of credit. This also means that only when the beneficiary fails to submit drafts such as commercial invoice, bill of lading or other documents involved in the letter of credit then issuer can refuse to pay. Otherwise, issuer must pay beneficiary even if the applicant happens to cause a breach of warranty, goes bankrupt or even in case the underlying contract is cancelled, the bank still have to pay the beneficiary in consideration that seller submit the documents complied with the credit $\left[{ }^{5}, \mathrm{pp}\right.$. 186-188]. The independence principle in the letter of credit is expressed through payment liability of the issuing bank $\left[{ }^{7}\right.$, p. 372].

Letter of credit remains its economically capacity by keeping parties in the letter of credit within their "zone of expertise" and this is also a part of the independence principle's purpose $\left[{ }^{11}\right.$, p. 522]. Independence principle is a fruit of merchants' customs just like the letter of credit. Among the three transactions, issuers play an important role in the second and 
third transaction and they are bankers- the experts in the banking business, not merchants $\left[{ }^{2}\right.$, p. 121]. So that, bank issuers of the letter of credit usually deal with paper examination and payment problems, not the quality of the goods $\left[{ }^{11}\right.$, pp. 522-523]. This regulation coheres with the position of the banks in three transactions because they are not related to the underlying contract; issuing bank does not govern the terms and the conditions of the participants in the underlying contracts. Henceforward, bank issuers cannot deal with the services or goods, and the letter of credit must be "paper-driven device whose operation must turn upon what appears on the face of paper, not upon circumstances outside them" $\left[{ }^{2}\right.$, p. 121]. Examining the documents is important to investigate whether the visible of documents tendered complies with the credit or not, yet issuers cannot define the compliance of the document in reality. $\left[{ }^{2}\right.$, p. 121]. Similarly, the sellers and buyers usually deal with consequences of quality and quantity of the products, sometime even the shipping of the goods [ ${ }^{11}$, p. 523]. Therefore, once the bank issuers in the third contract must handle the issues from the underlying contract, then they must be put in a position outside of their "zone of expertise" $\left[{ }^{11}\right.$, p. 523] and the independent of letter of credit will collapse $\left[{ }^{2}\right.$, p. 121$]$.

As written in their paper, Xiang Gao and Professor Buckley (2003) agreed that the principle of independence was somehow beneficiary-oriented because the risk of beneficiary which is not being paid would be reduced due to exercising of this principle. Nonetheless, the applicant might face risks of forged document when the beneficiary might present drafts conforming to the requirements of the credit but fails to perform it and still get honored by the issuing bank $\left[{ }^{2}\right.$, p. 122].

\section{Independence principle in United States Letter of Credit Law}

Because the usage of documentary credit in the international trading world is increasing, some countries had issued specified regulations to govern the letter of credit. United States is one of the independence countries having the code to conduct the process of documentary credit. The code contains the letter of credit law is the Uniform of Commercial Code, which consists of eleven articles covering differences in the commercial law. Article 5 of $\mathrm{UCC}^{\mathrm{e}}$ covers the definitions and the process of letter of credit. The first version of Article 5 in 1950s was not considered as "code" compared to other articles in UCC, it was drafted to create a theoretical framework which is independence

\footnotetext{
${ }^{\mathrm{e}}$ Uniform of Commercial Code, UCC, 1952.
}

and could be flourish later in the future ${ }^{12}$. In 1995, Article 5 was revised due to "weaknesses, gaps and errors in the original statute which compromise its relevance" ${ }^{13}$. The technologies used in documentary credit are also a reason to revise the Article 5. The revised version was presented in October 1995.

The independence principle is embodied in Article 5 of the Revised UCC as follows:

- "Rights and obligations of an issuer to a beneficiary or a nominated person under a letter of credit are independent of the existence, performance, or nonperformance of a contract or arrangement out of which the letter of credit arises or which underlies it, including contracts or arrangements between the issuer and the applicant and between the applicant and the beneficiary."

According to this section, the main obligation of bank issuers is honoring the documents on condition that the documents meet the conditions in the letter of credit. This obligation cannot be prevented from the applicant's accusation that the beneficiary does not fulfill their obligations in the underlying contracts. Issuing banks must pay for the documents tendered by beneficiary if the requirements in the letter of credit is met. If there are any problems raised from the sales contract related to the obligations of the merchant, buyer could recover his lost in a subsequent suit for breach of warranty [ ${ }^{7}$, p. 372].

Even though Article 5 was completed and adopted in the United State, nonetheless, UCP still plays an important role in the transactions happened in US. Most of the transactions using letter of credit as a payment method are international transactions which are conducted by the UCP. "Therefore, the UCP will be a more significant source of law than the UCC." ${ }^{14}$. The Article 5 might have some points in common with UCP, notwithstanding, it still remains as an official article in Uniform of Commercial Code. Article 5 mainly governs the liabilities and responsibility, even fraud rule, while lawyers specified in international banking can observe the operation of letter of credit practice through rules provided by UCP.

\section{FRAUD - EXCEPTION OF INDEPENDENCE PRINCIPLE AND FRAUD RULE}

\section{Definition of fraud}

Fraud is acknowledged as a part of the oldest and outstanding occurrences in the international trading world and so does the efforts of merchants to prevent it. "As long as there have been commercial systems 
in place, there have been those who have tried to manipulate these systems" $\left[{ }^{15}, \mathrm{p} .9\right]$. There are several companies had failed in managing the risks of being forged in international trade. The reasons for these failures might be because the international trade faces a lot of issues such as geological gap between sellers and buyers, shortage in protecting parties by law and differences between countries' legal systems. These rationales make fraud risks in international trade are much higher than in the domestic trade.

One of the earlies case related to letter of credit fraud is Higgins v. Steinhardter happened in 1919 in US. The plaintiff brought an action to stop the John Monroe Co. (the issuer) from obtaining and reimbursing for the documents presented by the defendant Jornet. The letter of credit clearly expressed that the shipment of walnut needed to be shipped before November 7 , 1918; bills of lading and consular invoice should accompany drafts against the credit. Plaintiff accused that the walnuts were not shipped by defendant from Spain until December, 1918 and plaintiff also brought the claim further to state that the shipment was made on October 30, 1918. Monroe Co. was notified by plaintiff facts stated above, nonetheless, the issuer still accepted and paid for the defendant ${ }^{16}$. The court noted and granted the injunction stating that the shipment was made after the date cited in the letter of credit, which was contrary the will of the applicant. Hence, "if shipment was made subsequent to that date, a payment made against said credit would be unauthorized" 16 .

This case happened in year 1919, the time when the letter of credit was taking its modern form [ ${ }^{1}, \mathrm{p}$. 37]. The court decided to grant an embargo to stop remittance based on facts that the defendant counterfeited the bill of lading, not on the foundation of fraud rule. Even the plaintiff made their claims on the facts that there was a false statement related to the shipment's date, not on a foundation of a cause of fraudulent action. The plaintiff sued the defendant for defaulted the contract, not for fraud $\left[{ }^{17}\right.$, p. 670]. Through this case, it seems like the fraud and fraud rule in the early $20^{\text {th }}$ century in the letter of credit case was at its beginning but merchants at that time did not realize it yet. Both the plaintiff and the judge referred to the rule of fraud, nonetheless, "they found another route to meet that end" $\left[{ }^{17}\right.$, p. 670$]$.

There was also a case in the 1920 s which the fraud disturbed the payment process. In the case Old Colony Trust Co. v. Lawyers' Title \& Trust Co., plaintiff had sold an amount of sugar to a seller. He was announced that the defendant issued a letter of credit in favor of the plaintiff ${ }^{18}$. The letter of credit stated that drafts must contain "net landed weight" and be made prior to November 30, 1920. The negotiable delivery orders or warehouse receipts must be attached along with the drafts. The problems were the net landed weight could only be confirmed once the customs weight the landed goods; and the warehouseman only issued the warehouse receipt if only the goods were under his actual possession. The drafts with other documents were presented to the bank issuer before the expire day even though the earliest date that the shipments cleared the customs was 30 December 1920 . The document was rejected by issuer based on the excuse that the document did not meet the requests stated in letter of credit. In an effort to recover from the breach of contract of the defendant, the applicant brought action to the Court. The Court rejected the claims of plaintiff [ ${ }^{18}$, p. 153]. The Second Circuit Court of Appeal maintained the original judgement and noted:

- "Obviously, when the issuer of a letter of credit knows that a document, although correct in form, is, in point of fact, false or illegal, he cannot be called upon to recognize such a document as complying with the terms of a letter of credit." $\left[{ }^{18}\right.$, p. 158$]$

In these two early cases, there were some similarities such as fraudulent documents and payments were stopped by the court also because of fraud. Nonetheless, the main difference between the Higgins and Old Colony is the foundation which the court based on to grant their judgements: in Old Colony, the court considered that the documents with fraud could not be seen as complying document while in Higgins, the payment was stopped because the court granted an embargo based on the foundation that the information in bill of lading were considered as "unauthorized".

\section{The fraud rule}

The court and parties in the letter of credit did not use the fraud exception to fight against the fraudulent documents in the early case of fraud in letter of credit $\left[{ }^{17}\right.$, p. 673]. The main point through the cases was the draft drawn under the letter of credit must be authentic and truthful, and the issuers do not have to obtain the document once the issuers are informed or discover by themselves that the documents are forgery or fraudulent.

\section{Fraud rule in UCP}

Until now, the UCP still remains silent about the rule of fraud and fraud standards. The excuse for this 
problem is UCP is not a law but a set of customs and practices in international trade using documentary credit payment. The UCP is considered as "rules of best banking practice, not rules for law" [ ${ }^{19}$, pp. 725727] and the fraud exception is considered as national problems so that if fraud is found in the documents then domestic laws should deal with granting prohibitions to block the process of letter of credit. However, this point of view leaves many problems. Even though UCP is not law, it is still recognized and used as "quasi-law in many countries that have little or no statutory law governing the letters of credit" $\left[{ }^{20}, \mathrm{pp}\right.$. 215-216]. Indeed, the UCP governs most of the letter of credit in the international trading world, which made UCP as "de facto law" 21 . So that, UCP need to work on the fraud and fraud rule to become a good model law.

\section{The Stzejn case - Sztejn v. Schroder Banking Corp}

The Sztejn case can be considered as milestone of the law of letter of credit in term of rule of fraud. This cases is cited and followed by several cases in US, England, Australia and other common law countries. It is also formed and codified in Uniform Commercial Code ("UCC") in Article 5.

In the Sztejn v. Schroder Banking Corp., the plaintiff, buyer Sztejn, bought bristles from an Indian company, Transea (the seller). The defendant was informed that he is the beneficiary in a letter of credit issued by Schroder which was requested by the plaintiff. The goods were loaded in fifty cases and placed on a steamship. The steamship company procured a bill of lading and customary invoices which were obtained by Transea ${ }^{22}$. Later, Transea tendered the drafts to presenting bank- Chartered Bank, who submit the documents to Schroder for payment. Before paying, applicant brought action to the court to block bank issuer to pay and stated that the seller, in fact, had "filled the fifty crates with cowhair, other worthless material and rubbish with intent to simulate genuine merchandise and defraud the plaintiff ..." 22 . Sztejn also claimed that "The Chartered Bank is not an innocent holder of the draft for value but is merely attempting to procure payment of the draft for Transea's account." $^{22}$. For purposes of the hearing court, all the claims by plaintiff was acknowledged to be true by Justice Shientag which means Transea had shipped trash and the Chartered Bank could not be considered as innocent holder in due course. The dismission of the Charter Bank about the plaintiff's claims was rejected by Justice Shientag mainly because of the commitment on establishing fraud in the sales contract $\left[{ }^{23}\right.$, p. 55].

From the point of Justice Shientag's view, the principle of independence was important, however, it should not be used as a shield to shelter the "unscrupulous seller" even drafts drawn from the letter of credit appearing to conform to the requirement from the letter of credit ${ }^{22}$.

Within this case, there were two other issues discussed:

First, the interest of the issuing bank. Justice Shientag stated that the fraud might also affected to interest of the issuing bank "Although the bank is not interested in the exact detailed performance of the sales contract, it is vitally interested in assuring itself that there are some goods represented by the documents" ${ }^{22}$.

Second, the immunity of the holders in due course. His Honor stated that "no hardship will be caused" when presenting bank or other holders in due course refuse to pay for the document claimed for fraud, or in case they was informed of the fraud in the documents presented "in the hand of one who stands in the same position as the fraudulent seller..." 22 .

While stating the important of independence principle "It is well established that a letter of credit is independent of the primary contract of sale between the buyer and the seller" ${ }^{22}$, Justice Shientag also created the foundation principle for the fraud rule as follows:

First, fraud is the only reason to halt the payment in the letter of credit. Breach of warranty does not count as one reason to halt any reimbursements in letter of credit.

Second, the fraud must be established and only precise allegation can cause the interruption.

Third, the payment for the holder in due course cannot be stopped even when the fraud is claimed.

Compared to the early $20^{\text {th }}$ century cases, even though we have to note that all of the claims of plaintiff was assumed to be true, the judgement in Sztejn case by Justice Shientag still made a big step in the law of documentary credit. In previous case discusses, fraud rule had never been mentioned or used. In this Sztejn case, not only this is the first case that the fraud rule was mentioned, Justice Shientag also established the clear guidance for the future cases relating to the fraud in letter of credit.

\section{Fraud rule in Prior and Revised Article 5 of UCC}

There is one source of fraud rule should be considered as model commercial rule is the Uniform Commercial Code of United States. The fraud rule is first 
mentioned in the Prior Version of Article 5 of UCC and after a few year, the Article 5 is revised with the Revised Version of Article 5 of UCC. The UCC is considered to be the first rule incorporated fraud in letter of credit.

\section{The Previous Version of Article 5 of UCC}

Since the Sztejn case, the fraud rule is embodied in Section 5-114(2), Article 5 of UCC which was draft in 1952:

- "Unless otherwise agreed when documents appear on their face to comply with the terms of a credit but a required document does not in fact conform to the warranties made on negotiation or transfer of a document of title (Section 7- 507) or of a certificated security (Section 8-108) or is forged or fraudulent or there is fraud in the transaction:

- (a) the issuer must honor the draft or demand for pay- ment if honor is demanded by a negotiating bank or other holder of the draft or demand which has taken the draft or demand under the credit and under circumstances which would make it a holder in due course (Section 3-302) and in an appropriate case would make it a person to whom a document of title has been duly negotiated (Section 7-502) or a bona fide purchaser of a certificated security (Section 8302); and

- (b) in all other cases as against its customer, an issuer acting in good faith may honor the draft or demand for payment despite notification from the customer of fraud, forgery or other defect not apparent on the face of the documents but a court of appropriate jurisdiction may enjoin such honor."

The creation of Section 5-114 was significant in the law of letter of credit because it was the first time that victims can use the fraud rule to protect themselves from fraud in letter of credit. The sufferers of referring to other codes or principles such as the contract law or affirming the documents were not fit with the requirement of letter of credit is no longer continuing. With the section 5-114(2), there were two circumstance which describe the fraud rule:

First, the issuing bank could be blocked from paying for the drafts drawn from the letter of credit by the Court's injunction if the documents tendered appearing to comply with the requirement but that "document ... is forged... or there is fraud in the transaction";
Second, if the frauds described above are given prominence to the bank issuer, the bank could invoke the fraud rule and turn the payment request down or decline the drafts.

However, even when the fraud exception was drafted in the code, one of the problems raised from the section was the standard of the fraud and how to deal with it [ ${ }^{24}$, pp. $\left.345-352\right]$. This issue led to the inconsistent in the interpreting the fraud exception that courts had applied various standards to define the fraud in the transaction or document. As a results, the standard was divided into several definitions of fraud such as "constructive fraud", "intentional fraud" or "egregious fraud" [ ${ }^{25}$, pp. 298-309].

As has been seen, the Section 5-114(2) was considered as a basic for future $\left[{ }^{17}\right.$, p. 684$]$, however, it is not entirely faultless and still remained several problems. Beside the lack of fraud standard, the confusion also lied in the guidance where to locate the fraud and the fraud rule: whether the fraud should only be examined in the documents drawn from the letter of credit only, or should we consider to extend the scope of fraud rule to the sales contract $\left[{ }^{17}\right.$, p. 684$]$. These problem led to the reduction of the financial benefits of the letter of credit in international trade [ ${ }^{7}$, p. 384$]$.

The revised Version of Article 5 of UCC

After more than 30 years, the UCC Committee of the American Bar Association decided to reevaluate and develop the Article $5^{13}$. The Task Force had reviewed the case law, new customs and practice as well as disclose the new technologies being used in the international trade. With those efforts, the rule of fraud is demonstrated in Article 5, Section 5-109 as follows:

"(a) If a presentation is made that appears on its face strictly to comply with the terms and conditions of the letter of credit, but a required document is forged or materially fraudulent, or honor of the presentation would facilitate a material fraud by the beneficiary on the issuer or applicant:

- (1) the issuer shall honor the presentation, if honor is demanded by (i) a nominated person who has given value in good faith and without notice of forgery or material fraud, (ii) a confirmer who has honored its confirmation in good faith, (iii) a holder in due course of a draft drawn under the letter of credit which was taken after acceptance by the issuer or nominated person, or (iv) an assignee of the issuer's or nominated person's deferred obligation that was taken for value and without notice of forgery or material fraud after the obligation was incurred by the issuer or nominated person; and 
- (2) the issuer, acting in good faith, may honor or dishonor the presentation

- in any other case.

(b) If an applicant claims that a required document is forged or materially fraudulent or that honor of the presentation would facilitate a material fraud by the beneficiary on the issuer or applicant, a court of competent jurisdiction may temporarily or permanently enjoin the issuer from honoring a presentation or grant similar relief against the issuer or other persons only if the court finds that:

- (1) the relief is not prohibited under the law applicable to an accepted draft or deferred obligation incurred by the issuer;

- (2) a beneficiary, issuer, or nominated person who may be adversely affected is adequately protected against loss that it may suffer because the relief is granted;

- (3) all of the conditions to entitle a person to the relief under the law of this State have been met; and

- (4) on the basis of the information submitted to the court, the applicant is more likely than not to succeed under its claim of forgery or material fraud and the person demanding honor does not qualify for protection under subsection (a)(1)."

As has been seen, the Revised Article 5, Section 5-109 of UCC had adjusted some problems with the fraud exception.

First, fraud standard, one of the most argumentative issues in the documentary credit, which was unsolved problem in the previous version of Article 5 was tackled. The Article 5, Section 5-109 embraces the standard as "material fraud". However, definition for "material fraud" was not defined. The fraud rule also be prescribed to locate in the drafts and in the sales contracts (Uniform of Commercial Code, 1952, Section 5-109).

Second, the process of letter of credit is only suspended once fraud is discovered in two circumstances: the bank issuers decide to turn the presentation of drafts down; or applicants ask the court to grant the injunctions to block the payment or presentation (Uniform of Commercial Code, 1952, Section 5-109).

Third, Section 5-109(a) (1) includes 4 type of participants who are immune from the fraud rule. This version is more related to the fraud rule and displays a great improvement.

Fourth, if documents are claimed forgery or fraudulent by applicant and he wants to enjoin the honor or presentation, issuing bank could be enjoined from honoring a submitted documents by beneficiary temporarily or permanently by Court and Court could issue relief opposed to issuing bank with four condition in Section 5-109(b).

With all the improvement, the Revised Article 5, Section 5-109 of UCC becomes one of the extensive regulations about rule of fraud in the documentary credit law and is used widely in common law. This Article 5 is also considered as the model law for other countries such as China. The whole UCC had been translated into Chinese and Article 5 was considered as a good legal source for modern letter of credit law [ ${ }^{17}$, pp. 683-684]. It is interesting when United States is a common law country but it is the first country to have written regulations about letter of credit and fraud rule.

\section{POSITION OF INDEPENDENCE PRINCIPLE IN VIETNAM LETTER OF CREDIT LAW}

The letter of credit law and fraud rule was barely mentioned in the legal literature of Vietnamese even the percentages of Vietnam international transactions make up a large part of the economy. Vietnam National Assembly had issued some legal documents about payment in international trade and the domestic letter of credit law, however the independence principle was not mentioned in the previous regulations, as well as the fraud rule.

One of the by-law document had mentioned the letter of credit was Decision 226/2002/QD-NHNN dated March 26th, 2002 on The Issuance of The Regulation on Payment Activities Through Payment Service Suppliers (herein "Decision 226/2002/QD-NHNN"). In Article 16 of Decision 226/2002/QD-NHNN, the definition of domestic letter of credit payment was explained and it fitted with the characterization in the UCP 600. The Decision defined and mentioned two ways of payment in letter of credit in Vietnam are (1) payment immediately and (2) payment at the instruction at a specific future time as followed:

- "1. Letter of credit shall be a conditional written undertaking opened by banks at the request of a payment service user (the applicant for opening the letter of credit), under which, banks shall perform the requests of the payment service users (the applicant for opening letter of credit) in order to:

- - Effect the payment or authorize other banks to effect the payment immediately at the instruction of the payee upon receipt of a set of presented documents satisfying the conditions of 
letter of credit; or

- - Accept to make the payment or authorize other banks to make the payment at the instruction of the payee at a specific future time upon receipt of a set of presented documents satisfying conditions of letter of credit.

- 2. The opening, issuance, amendment, notification, confirmation, examination of the payment documents and rights, responsibilities, etc. of related parties in payment by letter of credit shall be applicable upon the agreement of parties engaging in the payment and in accordance with current applicable laws of Vietnam."

Nonetheless, the principle of independence was not included in this Decision. Afterward, the Decision 226/2002/QD-NHNN was expired and replaced by the Circular 46/2014/TT-NHNN dated December 31, 2012 on Guidelines For Non-Cash Payment Services (herein "Circular 46/2014/TT-NHNN"). Circular 46/2014/TT-NHNN removes the whole Article 16 of Decision 226/2002/QD-NHNN which leads to the situation that Vietnam legal framework does not have any provisions related to domestic letter of credit payment and remains no provisions for independence principle in letter of credit.

Vietnam legal framework still have provisions declaring the independence rule but it is related to negotiable instrument, not letter of credit. In Section 2, Article 3 of Law on Negotiable Instruments dated on November 29, 2005 issued by National Assembly, the independence principle is recognized as follows:

- "The negotiable instrument relationships stipulated in this Law are independent and are not dependent on a transaction which is the basis for issuance of a negotiable instrument stipulated in clause 1 of this article" (Law on Negotiable Instrument, 2005, Art. 3).

This Law acknowledges principle of independence, one of the main rules in the international transactions but this Law does not govern the letter of credit because its governing scope is negotiable instruments in Article 1 including "bills of exchange, promissory notes, cheques and other negotiable instruments, excluding long-term negotiable instruments issued by organizations aimed at raising capital on the market" ${ }^{26}$. Under the light of Article 6 of Law on Negotiable Instrument, in the case of "negotiable instrument relationships involving foreign elements, the parties to the negotiable instrument relationship may agree to apply international commercial practices" 26 such as International Chamber of Commerce's Rules on Uniform Customs and Practice for documentary credits. So that, it means the Vietnam Legal System allows relationships containing foreign elements to have the UCP to govern the transactions, this is equivalent to domestic documentary credit is not governed by UCP or by any by-law documents. Vietnamese laws now do not have specific provisions on letter of credit so that once the dispute happens between Vietnam merchants and foreign partners related to fraud, the Courts or Arbitrations usually refer to the general provisions of the Civil Code, the Civil Procedure Code, the Commercial Law and other by-law documents. However, these regulations are not specified rules for letters of credit and UCP also has no provisions referring to fraud and fraud rules, so these issues cannot be solved, especially problems which are related to fraud issues. The amendment for letter of credit law and fraud rule is necessary for Vietnam, especially when the Vietnam Government is trying to impulse import-export activities and these activities normally require the payment using the letter of credit. The blank on the law of letter of credit might causes critical problems which harm the circle of law and the international trade world. The improper understanding about the letter of credit of the Court in specific situation such as the Legal precedent No. 03/2017 might threaten to both international reputation and the commercial utility of the letter of credit. In order to meet the demands on further economic reform and challenges in the future, especially when Vietnam is trying to access the international trade, author thinks a special judicial interpretation on the letter of credit in general and independence rule in particular is needed. A special Decision formed by the State Bank of Vietnam is a proper way to deal with foreign-related commercial and international letter of credit. This decision should be made and contained rules to provide guides for Court to deal with foreignrelated commercial and international letter of credit. The Decision must contain the substantive and procedural matters of the law which is the fraud standards, those who can be immune from the fraud rule, those who can bring case to the court for applying the fraud exception and other detailed court procedure.

\section{CONCLUSION}

The documentary credit has gone a long way until its beginning and still keeps its commercial utility created by merchants. The principle of independence is also a creation of the international merchants since it is used to protect the buyer by asking the sellers to present the authentic drafts complied with the requirements of the letter of credit to get paid. However, there are some persons trying to manipulate this 
process and defraud with this measurement. Therefore, the fraud rule has started to grow and there are some countries tried to embodied it in their domestic law. For some view, the fraud rule is lowering the financial benefits of the letter of credit and applicants of letter of credit should protect themselves from the fraudsters [ ${ }^{7}$, p. 418]. However, I believe that the main task of the rule of fraud is reduce the risks of being forgery of fraudsters and stop them violate the system of letter of credit, this effort helps sincere letter of credit applicants feel more comfortable to use documentary credit. In some ways, the commercial efficiency of documentary credit is protected by the fraud rule.

To establish a whole new legal system for letter of credit which is a sophisticated area, legislators are required to perform fully their expertise and prepare detailed rules to make sure the system operation will continuously work. One of the most serious issues in defining letter of credit law is to ensure the commercial utility by remaining the independence principle. Definition of fraud rule is also very important because setting a standard for fraud rule is quite complex. If we set the standard too high, the fraud rule would lose its effectiveness. If the standards are too low, the applicant may use the rule of fraud as an instrument to violate the autonomy principle by stopping the payment from the issuer to the beneficiary. Fraud rule standards must serve it function for the fraud rule as well as workable for the court. It is still a long way to go for Vietnam legal system to harmonize the letter of credit law into the domestic law and maintain the independence principle. Intergrating the fraud rule in national law is also complicated because fraud rule is an exception of law of documentary credit since it conflicts with the independence principle. The legislators need to consider other legal sources such as the UCP, UN Convention as well as approach other domestic law of foreign countries such as United States or China. The documentary credit law including autonomy principle and rule of fraud may have even greater effect in Vietnam because Vietnam is a civil law country. In investigating the sources of law, civil countries normally count on statuses rather than cases. Letter of credit existed because of faith between parties, once the frauds happen, the faith must be faded then parties will no longer use this kind of payment anymore.

\section{LIST OF ABBREVIATIONS}

ICC: The International Chamber of Commerce

UCP: Uniform of Customs and Practice

UCC: Uniform of Commercial Code

US: United States of America

\section{UNCITRAL CONVENTION}

United Nations Convention on Independence Guarantees and Standby Letter of Credit

\section{CONFLICT OF INTEREST}

I hereby confirm that the manuscript has no actual or potential conflict of interest with any party, including but not limited to any financial, personal or other relationship with other people or organization within three years of beginning the submitted work that could inappropriately influence or be perceived to influence.

\section{AUTHOR'S CONTRIBUTION}

The works of the article is solely done by author.

\section{REFERENCES}

1. Ellinger E. The Uniform Customs- Their nature and the 1983 Revision. Lloyd's Mar \& Com LQ. 1984;p. 578-579.

2. Xiang G, Buckley RP. The Unique Jurisprudence of Letter of Credit: Its Origin and Source. San Diego International Law Journal. 2003;4:91-126.

3. International Chamber of Commerce, Uniform Customs and Practices. 1993;.

4. International Chamber of Commerce, U.C.P 600. 2007;

5. Ellinger EP. Documentary Letter of Credit- A comparative Study, Singapore. University of Singapore Press. 1970;.

6. Richard J, Dole F. The Effects of UCP 600 upon UCC Article 5 with Respect to Negotiation Credits and the Immunity of Negotiating Banks from Letter of Credit Fraud. Wayne Law Review. 2008;54.

7. Flint RE. Letter of credit, and the Uniform Commercial Code: It is time to Untether the Independence Principle. Baylor Law Review. 2019;71(2):353-420.

8. I. C. o. Commerce, Uniform of Practice and Customs. 2007;

9. McLaughing GT. The ABC's of Letter of Credit: Important Financial Instruments. National Law Journal. 1986;.

10. Howard DC. The Application of Compulsory Joinder Intervention, Impleader and Attachment to Letter of Credit Litigation. Fordham Law Review. 1984;52:957-966.

11. McLaghlin GT. Exploring Boundaries: A legal and Structural Analysis of the Independence Principle of Letter of Credit Law. Banking Law Journal. 2002;119(6):501-565.

12. Official Comment 1, Original UCC Art.5. 1995;

13. Task Force. Study of U.C.C Article 5, report, An Examination of U.C.C Article 5 (Letter of Credit). 1990;45:1521-1532.

14. White JJ, Summers RS. 3 Uniform Commercial Code 120, 4th Edition ed. West Publishing Co. 1995;

15. Int'I Chamber of Commerce. ICC Commercial Crime Bureau Special Report- Prime Bank Instrument Frauds. 1994;.

16. Higgins v. Steinhardter. 1919;.

17. Buckley RP, Gao X. Development of the fraud rule in letter of credit law: The journey so far and the Road ahead. University of Pennsylvania Journal of International Economic Law. 2002;p. 663-712.

18. Old Colony Trust Co. v. Lawyers Title \& Trust Co. 1924;

19. Goode RM. Commercial Law, 2nd Edition ed. 1995;.

20. Barnes JG, Byrne JE. Revision of U.C.C. Article 5. Business Lawyer American Bar Association. 1995;50:1449-1459.

21. Dolan JF. The law of Letter of credit: Commercial and Standby Credits. Warren, Gorham \& Lamont Incorporated, USA. 1996;4.

22. Sztejn v. Henry Schroder Banking Corp. 1941; 
23. Alavi H. Autonomy principle and fraud exception in Documentary Letters of creidt, a comparative study between United States and England. International and Comparative Law review. 2015;15(2):47-68. Available from: https://doi.org/ 10.1515/iclr-2016-0035.

24. Symons ELJ. Letter of credit: Fraud, Good faith and the Basics for Injunctive Relief. Tulane Review. 1979-1980;54(2):338-381.
25. Gao X, Buckley RP. Acomparative analysis of the standard of Fraud required under the Fraud rule in Letter of Credit Law. Duke Journal of Comarative \& International Law. 2003;13(2):293-336.

26. ot S R o C. Vietnam, Law on Negotiation Instrument. 2005; 


\title{
Nguyên tắc độc lập và ngoại lệ trong thư tín dụng chứng từ: Đề xuất cho Việt Nam
}

\author{
Bùi Lê Thục Linh ${ }^{1,2, *}$
}

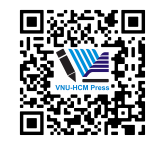

Use your smartphone to scan this QR code and download this article
${ }^{1}$ Nghiên cứu sinh tại Géza Marton Doctoral School of Legal Studies Truờng Đại học Debrecen

${ }^{2}$ Giảng viên tại Trường Đại học Kinh tếLuật, Đại học Quốc gia TP.HCM, Việt Nam

Liên hệ

Bùi Lê Thục Linh, Nghiên cứu sinh tại Géza Marton Doctoral School of Legal Studies Trường Đại học Debrecen

Giảng viên tại Trường Đại học Kinh tế- Luật, Đại học Quốc gia TP.HCM, Việt Nam

Email: linhblt@uel.edu.vn

Lịch sử

- Ngày nhận: 07/04/2020

- Ngày chấp nhận: 21/9/2020

- Ngày đăng: 7/10/2020

DOI : 10.32508/stdjelm.v4i4.591

\section{Check for updates}

\section{Bản quyền}

๑ ĐHQG Tp.HCM. Đây là bài báo công bố mở được phát hành theo các điều khoản của the Creative Commons Attribution 4.0 International license.

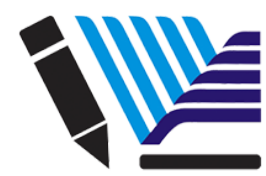

VNU-HCM Press

\section{TÓM TẮT}

Mặc dù thư tín dụng chứng từ đã được sử dụng từ rất lâu, tuy nhiên các văn bản pháp lý của Việt Nam vẫn chưa để cập nhiếu đến các tính chất pháp lý của thư tín dụng chứng từ. Phòng Thương mại Quốc tế ("ICC") đã ban hành bộ Quy tắc và Thực hành thống nhất về Tín dụng chứng từ (Uniform of Customs and Practice- UCP) từ năm 1933 và bô Quy tắc này vẫn được tiếp tuc cập nhật cho đến ngày nay. hiên bản mới nhất là UCP 600 được phát hành vào năm 2007, tuy nhiên, có một số vấn đề không được đề cập tới trong phiên bản mới nhất này vì ICC cho rằng những vấn đề đó thuộc phạm vi quy định của mỗi quốc gia. Tuy nhiên, các quốc gia khác nhau sẽ có những quy định riêng nên dẫn đến việc các thương nhân sẽ bị bối rối khi tham gia vào các hoạt động thương mại quốc tế. Tại một số quốc gia, UCP được coi như là "quasi-law" ("tương tự như luật") vì họ không có quy định cụ thể về thư tín dụng chứng từ, trong khi đó, một số quốc gia khác lại có khung pháp lý riêng cho thư tín dụng chứng từ và thậm chí có cả quy chuẩn gian lận trong thư tín dụng. Hoa Kỳ tuy là một quốc gia thuộc hệ thống Thông luật nhưng lại là quốc gia đầu tiên nội luật hoá các quy tắc và hoạt động của thư tín dụng chứng từ cũng như quy định tiêu chuẩn gian lận của thư tín dụng chứng từ trong Bộ luật Thương mại (Uniform of Commercial Code- UCC). Trong phạm vi bài viết này, tác giả sẽ giải thích và so sánh nguyên tắc độc lập trong cả UCP và UCC, đônn thời làm rõ định nghĩa và quy định về quy chuẩn gian lận trong UCC và đánh giá các quy định pháp lý của luật pháp Việt Nam đối với nguyên tắc độc lập trong thư tín dụng.

Từ khoá: thư tín dụng chứng từ, gian lận, quy chuẩn gian lận, UCP, UCC
Trích dẫn bài báo này: Linh $B L$ T. Nguyên tắc độc lập và ngoại lệ trong thư tín dụng chứng từ: Đề xuất cho Việt Nam. Sci. Tech. Dev. J. - Eco. Law Manag.; 4(4):997-1008. 